\title{
LOYALITAS WISATAWAN TERHADAP CITRA PULAU LOMBOK SEBAGAI DAERAH TUJUAN WISATA HALAL
}

\author{
Oleh \\ Sri Susanty \\ Sekolah Tinggi Pariwisata Mataram \\ Email: srisusantympar@gmail.com
}

\begin{abstract}
Abstrak
Penelitian ini bertujuan untuk mengetahui pengaruh citra destinasi terhadap loyalitas wisatawan dengan variabel kepuasan wisatawan sebagai mediasi. Sampel yang digunakan dalam penelitian ini adalah 100 responden yang merupakan wisatawan yang mengunjungi daerah tujuan wisata halal Pulau Lombok. Data diambil dengan menggunakan Purposive Sampling dan menggunakan Metode analisis Partial Least Square (PLS) untuk mengetahui pengaruh variabel-variabel yang terlibat. Hasil penelitian ini menunjukkan bahwa citra destinasi berpengaruh terhadap loyalitas wisatawan. Semakin tinggi citra destinasi yang dirasakan, semakin tinggi kepuasan wisatawan, maka semakin kuat pula loyalitas wisatawan yang dimiliki oleh wisatawan.

Kata kunci: Loyalitas Wisatawan, Kepuasan Wisatawan, Daerah Tujuan Wisata Halal \& Pulau Lombok.
\end{abstract}

\section{PENDAHULUAN}

Nusa Tenggara Barat (NTB) khususnya Pulau Lombok merupakan salah satu daerah tujuan wisata halal yang mulai dilirik keberadaanya karena wisata alam dan budaya yang dimilikinya. Salah satu factor yang berperan dalam pengembangan pariwisata Lombok adalah kehadiran Bandara Internasional Lombok (BIL) di Kabupaten Lombok Tengah yang mulai beroperasi pada tahun 2011 menggantikan Bandara Selaparang yang terletak di Kota Mataram. Apresiasi terhadap branding pariwisata halal Lombok ditunjukkan dengan dinobatkannya Pulau Lombok menjadi tujuan wisata halal dunia pada ajang World Travel Halal Awards 2015 dan 2016. Pada tahun 2016, pemerintah telah menetapkan sepuluh destinasi pariwisata " 10 Bali Baru" yang menjadi prioritas pengembangan pariwisata di Indonesia yaitu Danau Toba (Sumut), Belitung (Babel), Tanjung Lesung (Banten), Kepulauan Seribu (DKI Jakarta), Candi Borobudur (Jateng), Gunung Bromo (Jatim), Pulau Komodo (NTT), Taman Nasional Wakatobi (Sulawesi Tenggara), Morotai (Maluku Utara), dan Mandalika Lombok (NTB). Kawasan Ekonomi
Khusus (KEK) Mandalika dengan luas sekitar 1.175 hektar telah diresmikan operasionalnya oleh Presiden Joko Widodo Pada Tanggal 20 Oktober 2017. Kawasan yang dikelola oleh Indonesia Tourism Development Corporation (ITDC) akan berkontribusi besar dalam pertumbuhan investasi pariwisata di Pulau Lombok.

Menurut data yang telah dihimpun oleh Dinas Pariwisata NTB (2017) bahwa pertumbuhan industri pariwisata di NTB mengalami kenaikan yang cukup signifikan, yakni 22 persen pada 2017 atau meningkat sebesar 3 persen dibandingkan 2016 yang sebesar 19 persen. Tumbuhnya investasi di bidang pariwisata tak lepas dari capaian apik NTB dalam menggaet wisatawan. Tercatat selama 2017, NTB berhasil mendatangkan 3,5 juta wisatawan Sedangkan pada 2016, NTB mampu mendatangkan 3.094.437 juta wisatawan atau sedikit lebih tinggi dari angka kunjungan yang ditargetkan sebesar 3 juta wisatawan. Adapun jumlah wisatawan yang berkunjung ke NTB dalam 5 tahun terakhir sebagaimana terlihat pada Tabel 1 
Tabel 1. Perkembangan/Persentase Jumlah kunjungan wisatawan ke NTB tahun 20132017

\begin{tabular}{|c|c|c|c|c|c|}
\hline $\mathrm{N}_{0}$ & Tahum & Wisman & Wisums & Jumlah & Perkembangan(\$) \\
\hline 1 & 2013 & 565.944 & 791.658 & 1.357 .602 & 16.32 \\
\hline 2 & 2014 & 752.306 & 876.816 & $1.629: 122$ & 2000 \\
\hline 3 & 2015 & 1.061 .292 & 1.149 .235 & 2.210527 & 35.69 \\
\hline 4 & 2016 & 1.004 .328 & 1.690 .109 & 3.094 .437 & 39.99 \\
\hline 5 & 2017 & 1.430 .249 & 2.078 .654 & 3.508 .903 & 13.39 \\
\hline
\end{tabular}

Sumber: Dinas Provinsi NTB, 2017

Peningkatan jumlah wisatawan yang berkunjung ke Lombok antara lain disebabkan oleh diversifikasi daya tarik wisata, sarana dan prasarana wisata yang memadai, kerjasama yang baik antar stakeholder pariwisata, dan promosi yang gencar dilakukan. Penelitian ini bertujuan untuk mengukur loyalitas wisatawan terhadap citra daerah tujuan wisata halal Pulau Lombok.

\section{LANDASAN TEORI}

Lawson dan Bovy dalam Lopes (2011) mendefinisikan konsep citra destinasi sebagai ekspresi dari semua pengetahuan obyektif, prasangka, imajinasi, dan pikiran emosional seorang individu atau kelompok tentang lokasi tertentu. Dalam pariwisata, pembangunan citra daerah tujuan terjadi dari gabungan antara informasi yang didengar dan persepsi daerah tujuan wisata itu sendiri, seperti gambaran alamnya, kesopanan penduduknya, kebudayaan dan lain-lain. Indikator citra destinasi yang ditetapkan oeh Tasci dan Gartner's (2007) yaitu (1) Reputasi. (2) Daya tarik natural. (3) Hiburan dan acara. (4) Daya tarik bersejarah dan budaya. (5) Aksesibilitas destinasi. (6) Tingkat kualitas pelayanan. Kotler dan Keller (2009) mengemukakan, bahwa loyalitas merupakan komitmen yang dipegang secara mendalam untuk membeli atau mendukung kembali produk atau jasa yang disukai di masa depan meski pengaruh situasi dan usaha pemasaran berpotensi menyebabkan pelanggan beralih. Indikator loyalitas wisatawan menurut Bigne et al., (2001): (1) Direkomendasikan. Kembali. (3) Kualitas. (4) Kepuasan. Oliver (1997) mendefinisikan kepuasan sebagai penilaian bahwa fitur produk atau layanan memberikan tingkat konsumsi yang menyenangkan. Indikator kepuasan wisatawan menurut Kozak dan Rimmington (2000); Lee, Back, dan Kim's (2009): (1) Perbelanjaan. (2) Aktivitas. (3) Penginapan. (4) Ketersediaan informasi perjalanan. (5) Makanan. (6) Iklim. (7) Daya tarik. (8) Lingkungan. (9) Tamasya. Tasci dan Gartner (2007) dalam Artuğer et al., (2013) menerangkan bahwa citra destinasi mempengaruhi perilaku wisatawan seperti bermaksud mengunjungi kembali, merekomendasikannya ke orang lain, atau berkunjung kembali ke destinasi pariwisata. Artuğer et al., (2013) melalui penelitiannya juga membuktikan bahwa terdapat hubungan yang kuat dan positif antara citra destinasi dengan loyalitas. Berdasarkan hal tersebut dapat disimpulkan bahwa perilaku wisatawan di masa depan yang menilai positif terhadap citra suatu destinasi pariwisata kemungkinan adalah mengunjungi kembali dan merekomendasikan destinasi pariwisata terkait kepada orang lain.

Oleh karena itu dapat disimpulkan hipotesisnya sebagai berikut: $\mathrm{H} 1$ : Citra destinasi berpengaruh terhadap loyalitas wisatawan Gartner (1989) mengemukakan, bahwa destinasi dengan citra yang lebih positif akan menjadi bagian dari proses pengambilan keputusan. Court dan Lupton (1997) mengemukakan, bahwa citra destinasi yang diteliti secara positif mempengaruhi niat pengunjung untuk kembali ke masa depan. Citra akan mempengaruhi bagaimana konsumen memandang kualitas. Citra positif sesuai dengan kualitas yang dirasakan lebih tinggi, yang pada gilirannya akan menentukan kepuasan konsumen (Kozak \& Rimmington, 2000). Oleh karena itu dapat disimpulkan hipotesisnya sebagai berikut: $\mathrm{H} 2$ : Citra destinasi mempengaruhi kepuasan wisatawan Di industri pariwisata, beberapa bukti empiris menunjukkan bahwa kepuasan wisatawan merupakan indikator kuat untuk meninjau kembali dan merekomendasikan destinasi kepada orang lain (Kozak \& Rimmington, 2000; Hultman et al 2015). Kepuasan mengarah 
pada rekomendasi pembelian berulang dan kata positif dari mulut ke mulut. Oleh karena itu dapat disimpulkan hipotesisnya sebagai berikut: H3 : Kepuasan wisatawan berpengaruh terhadap loyalitas wisatawan Lovelock et al. (2010) menjelaskan bahwa loyalitas sejati terletak pada kepuasan pelanggan (wisatawan) dimana wisatawan yang sangat puas atau menyenangi layanan cenderung menjadi pendukung yang loyal terhadap perusahaan (destinasi pariwisata). Bentuk loyalitas tersebut dapat berupa menggabungkan semuapembelian dengan satu penyedia layanan, dalam hal pariwisata yaitu dengan kembali berkunjung ke suatu destinasi yang sama, dan menyebarkan berita positif terkait destinasi.

\section{METODE PENELITIAN}

Pemilihan sampel dilakukan dengan teknik purposive sampling dimana peneliti memberikan kriteria tertentu dalam penarikan sampel. Karakteristik yang digunakan dalam penelitian ini adalah: 1) Responden merupakan wisatawan muslim domestik yang pernah mengunjungi wisata Pulau Lombok minimal lebih dari dua kali. 2) Responden merupakan wisatawan yang berasal dari luar Pulau Lombok. 3) Responden berusia rata-rata diatas 17 tahun. Jumlah sampel penelitian ditetapkan sebanyak 100 responden. Dalam penelitian ini untuk mengukur pengaruh variabel citra destinasi terhadap loyalitas wisatawan di Pulau Lombok menggunakan SEM berbasis varian yaitu Partial Least Square (PLS) yang menggunakan software SmartPLS 3.0. Variabel operasional dalam penelitian ini adalah: 1 . Variabel eksogen atau independent variable Citra Destinasi sebagai variabel eksogen (X1) 2. Variabel eksogen atau independent variable kedua adalah Loyalitas Wisatawan (X2). 3. Variabel dependen (variabel terikat) yaituLoyalitas Wisatawan (Y), variabel yang dipengaruhi oleh variabel lain yaitu Citra Destinasi dan Kepuasan Wisatawan. Variabel ini sering juga disebut dengan variabel endogen.
HASIL DAN PEMBAHASAN

Hasil Pengujian Partial Least Square (PLS)

1. Model Pengukuran (Outer Model)

Model pengukuran adalah model

yang mendeskripsikan hubungan antar

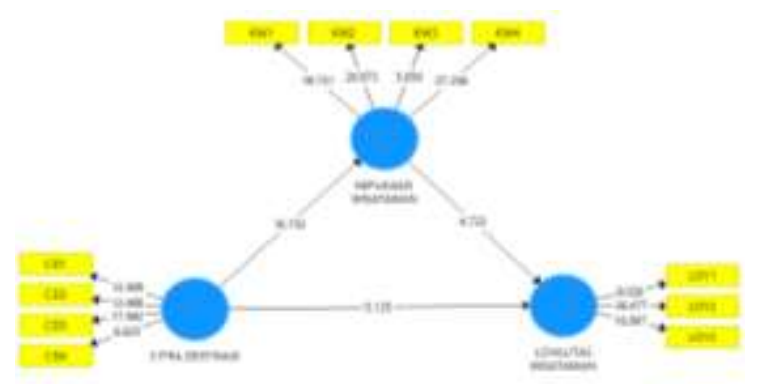

variabel laten (konstruk) dengan indikatornya. Hasil analisis outer model penelitian terlihat pada Gambar 1.

\section{Gambar 1. Hasil analisis outer model} penelitian

Sumber: PLS, 2018

a. Uji Validitas

Evaluasi pengukuran outer model PLS adalah untuk mengetahui validitas dan reliabilitas indikator-indikator yang mengukur variabel laten. Kriteria uji validitas pada sebuah penelitian mengacu pada besaran outer loading setiap indikator terhadap variabel latennya. Terdapat tiga kriteria didalam penggunaan teknik analisis data dengan SmartPLS untuk menilai outer model yaitu convergent validity, discriminant validity, serta average variance extracted (AVE) dan composite reliability (Ghozali, 2008). Outer model dinilai dengan cara melihat convergent validityseperti terlihat pada Tabel 2. Penelitian ini menggunakan batas minimal loading factor sebesar 0,5.

Tabel 2. Outer Loadings

\begin{tabular}{|l|c|c|c|}
\hline & $\begin{array}{c}\text { Citra } \\
\text { Destinasi }\end{array}$ & $\begin{array}{c}\text { Kepuasan } \\
\text { Wisatawan }\end{array}$ & $\begin{array}{c}\text { Loyalitas } \\
\text { wisatawan }\end{array}$ \\
\hline $\begin{array}{l}\text { CD-1 Daerah tujuan } \\
\text { wisata halal Pulau } \\
\text { Lombok memiliki } \\
\text { reputasi yang baik. }\end{array}$ & 0,733 & & \\
\hline $\begin{array}{l}\text { CD-2 Daerah tujuan } \\
\text { wisata halal Pulau } \\
\text { Lombok memiliki } \\
\text { daya tarik budaya } \\
\text { dan sejarah yang } \\
\text { menarik. }\end{array}$ & & & \\
\hline $\begin{array}{l}\text { CD-3 Daerah tujuan } \\
\text { wisata halal Pulau } \\
\text { Lombokmenyeleng } \\
\text { arakan hiburan }\end{array}$ & 0,780 & & \\
\hline
\end{tabular}




\begin{tabular}{|c|c|c|c|}
\hline $\begin{array}{l}\text { dan acara yang } \\
\text { menarik }\end{array}$ & & & \\
\hline $\begin{array}{l}\text { CD-4 Kemudahan } \\
\text { dalam mengakses } \\
\text { daerah } \\
\text { tujuan wisata halal } \\
\text { Pulau Lombok } \\
\end{array}$ & 0,558 & & \\
\hline $\begin{array}{l}\text { KW-1 Saya puas } \\
\text { dengan daerah tujuan } \\
\text { wisata } \\
\text { halal Pulau Lombok } \\
\text { memiliki } \\
\text { penginapan yang } \\
\text { layak. }\end{array}$ & & 0,832 & \\
\hline $\begin{array}{l}\text { KW-2 Saya puas } \\
\text { dengan daerah tujuan } \\
\text { wisata } \\
\text { halal Pulau Lombok } \\
\text { karena memiliki } \\
\text { ketersediaan } \\
\text { informasi perjalanan } \\
\text { yang akurat. }\end{array}$ & & 0,548 & \\
\hline $\begin{array}{l}\text { KW-3 Saya puas } \\
\text { dengan daerah tujuan } \\
\text { wisata } \\
\text { halal Pulau Lombok } \\
\text { karena memiliki } \\
\text { kuliner yang halal. }\end{array}$ & & 0,841 & \\
\hline $\begin{array}{l}\text { KW-4 Saya puas } \\
\text { dengan Daerah } \\
\text { tujuan } \\
\text { wisata halal Pulau } \\
\text { Lombok karena } \\
\text { memiliki daya tarik } \\
\text { yang menarik. }\end{array}$ & & & 0,690 \\
\hline $\begin{array}{l}\text { LOY-1Saya akan } \\
\text { merekomendasikan } \\
\text { kepada } \\
\text { calon konsumen lain } \\
\text { untuk } \\
\text { mengunjungi daerah } \\
\text { tujuan wisata } \\
\quad \text { halal Pulau } \\
\text { Lombok }\end{array}$ & & & 0,838 \\
\hline $\begin{array}{l}\text { LOY-2 Saya akan } \\
\text { mengunjungi daerah } \\
\text { tujuan wisata halal } \\
\text { Pulau Lombok di } \\
\text { masa depan } \\
\text { LOY-3Saya akan } \\
\text { mengatakan hal } \\
\text { positif } \\
\text { tentang daerah } \\
\text { tujuan wisata halal } \\
\text { Pulau Lombok }\end{array}$ & & & 0,815 \\
\hline
\end{tabular}

Sumber: PLS, 2018

Convergent validity adalah mengukur validitas indikator reflektif sebagai pengukur variabel yang dapat dilihat dari outer loading dari masing-masing indikator variabel. Berdasarkan Gambar 2. Hasil Outer Loading dapat dilihat bahwa sebagian besar nilai outer loading di atas 0,70 , tetapi masih terdapat nilai outer loading dibawah 0,70 yaitu antara 0,50 dan 0,60. Nilai ini masih dapat ditolerir sehingga tetap digunakan dalam model PLS.

Kriteria pertama untuk pengukuran discriminant validity indikator reflektif dapat dilihat pada cross loading antar indikator dan konstruknya. Nilai cross loadingdapat dilihat pada Gambar 3.

\section{Gambar 3. Hasil Cross Loading}

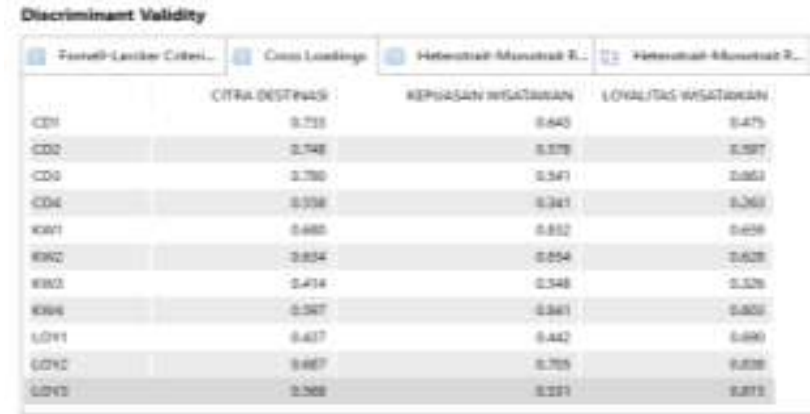

Sumber : PLS, 2018

Berdasarkan Gambar 3, korelasi konstruk antara citra destinasi dengan indikatornya lebih tinggi dibandingkan konstruk lainnya, yaitu korelasi CD1 dengan Citra Destinasi sebesar 0,733 lebih besar dibandingkan korelasi CD1 dengan Kepuasan Wisatawan $(0,643)$ maupun korelasi CD1 dengan Loyalitas Wisatawan $(0,475)$, begitu pula untuk CD2 - CD4. Hal yang sama juga berlaku untuk indikator KW1 - KW4 dan LOY1 - LOY3. Dengan demikian ketiga variabel dalam penelitian ini dapat dikatakan memiliki validitas diskriminan yang baik.

Kriteria kedua untuk discriminant validity adalah dengan membandingkan akar dari Average Variance Extracted (Akar AVE) untuk setiap konstruk dengan korelasi antara konstruk dengan konstruk lainnya dalam model.

\section{Gambar 4. Hasil Korelasi antar variable}

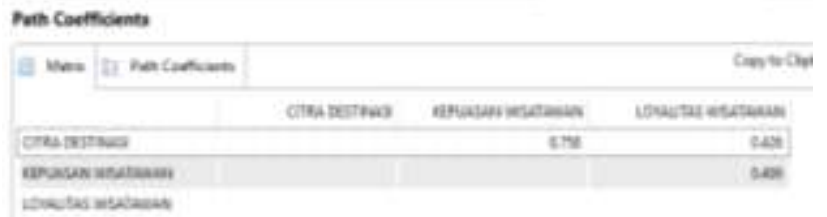

Sumber: PLS, 2018 


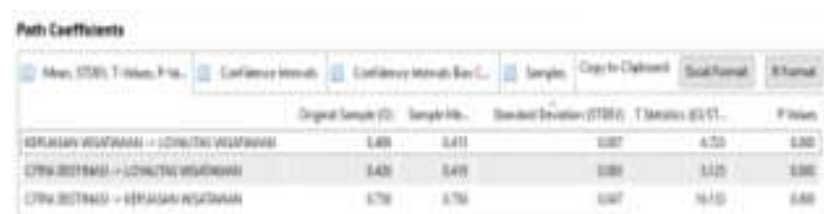

Sumber: PLS, 2018

Tabel 3. Akar AVE

\begin{tabular}{|l|c|c|}
\hline Indikator & $\begin{array}{c}\text { Average Variance } \\
\text { Extracted } \\
\text { (AVE) }\end{array}$ & $\begin{array}{c}\text { Akar } \\
\text { AVE }\end{array}$ \\
\hline Citra Destinasi & 0,504 & 0,709 \\
Kepuasan Wisatawan & 0,607 & 0,779 \\
Loyalitas wisatawan & 0,614 & 0,784 \\
\hline
\end{tabular}

Berdasarkan Gambar 4 dan Tabel 3, dapat dilihat bahwa korelasi maksimal variabel Citra Destinasi dengan variabel Kepuasan Wisatawan sebesar 0,758 dan korelasi maksimal variabel Citra Destinasi dengan variabel Loyalitas Wisatawan sebesar 0,426; sedangkan nilai akar AVE Citra Destinasi adalah sebesar 0,709 dan nilai akar AVE Kepuasan Wisatawan adalah 0,779. Korelasi maksimal variabel Kepuasan Wisawatan dengan variabel Loyalitas Wisatawan sebesar 0,409, sedangkan nilai akar AVE Loyalitas Wisatawan adalah sebesar 0,784. Dikarenakan nilai akar AVE dari ketiga variabel penelitian lebih besar dibandingkan nilai korelasi antar variabel, maka dapat dikatakan bahwa variabel dalam penelitian ini memiliki validitas diskriminan yang baik.

\section{b. Uji Reliabilitas}

Selain uji validitas konstruk, juga dilakukan Uji Reliabilitas konstruk. Penggunaan indikator sebagai item-item pertanyaan dari data variabl penelitian mensyaratkan adanya suatu pengujian konsistensi melalui uji reliabilitas, sehingg adata yang digunakan tersebut benar-benar dapat dipercaya atau memenuhi aspek kehandalan untuk dianalisis lebih lanjut. Uji reliabilitas dalam penelitian ini menggunakan dua ukuran, yaitu Cronbach's Alpha dan Composite Reliability. Nilai ini mencerminkan reliabilitas semua indikator dalam model. Besaran nilai minimal ialah 0,7 sedangkan idealnya adalah 0,8 atau 0,9. Selain Cronbach's Alpha digunakan juga nilai Composite Reliability yang harus bernilai di atas 0,60.

Gambar 5. Hasil Uji Reliabilitas

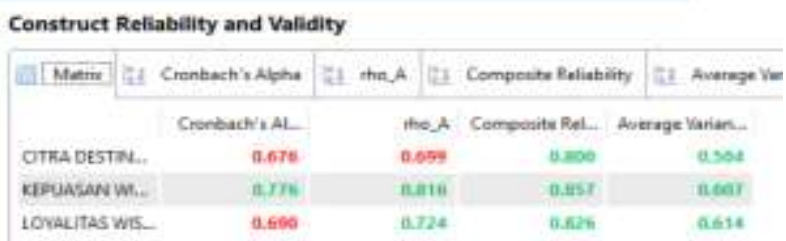

Sumber: PLS, 2018

Berdasarkan Gambar 5 dapat diketahui bahwa nilai Cronbach's Alpha dan Composite Reliability untuk semua variabel pada penelitian ini telah memenuhi kriteria yang ditetapkan sehingga dapat dikatakan bahwa variabel dalam penelitian ini reliabel.

\section{Model Struktural (Inner Model)}

Model struktural adalah model yang mendeskripsikan hubungan antar konstruk (variabel laten). Pengujian inner model dilakukan dengan pengujian hipotesis penelitian. Pengujian hipotesis didasarkan pada nilai t-statistik pada tampilan output bootstrapping program smart PLS dengan nilai t-tabel. Jika t-statistics lebih tinggi dibandingkan nilai t-table, berarti hipotesis terdukung. Pengujian dengan level signifikansi $5 \%$, memiliki nilai t-table sebesar 1,96 untuk hipotesis dua arah, dan 1,64 untuk hipotesis satu arah. Dalam penelitian ini penulis menggunakan hipotesis dua arah, sehingga memiliki nilai t-table sebesar 1,96. Untuk menolak/menerima hipotesis menggunakan probabilitas maka Ha diterima jika nilai p-value lebih kecil dari 0,05. Hasil pengujian hipotesis dapat dilihat pada Gambar 6.

\section{Gambar 6. Uji Hipotesis}

Path Cotificats

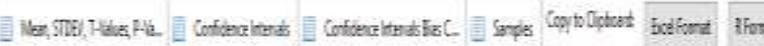

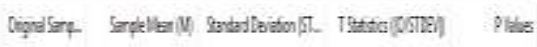

\begin{tabular}{|c|c|c|c|c|}
\hline 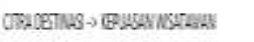 & $c 0$ & $17 x$ & MP & 1613 \\
\hline 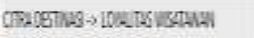 & $C B$ & 19 & 遇 & stb \\
\hline 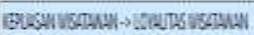 & ces & 245 & $u r$ & $47 i$ \\
\hline
\end{tabular}

Sumber: PLS, 2018

Berdasarkan hasil uji hipotesis sebagaimana tertuang dalam Gambar 6 dapat diketahui bahwa:

a. Pengaruh citra destinasi terhadap kepuasan wisatawan (H1) ditunjukkan dengan koefisien beta sebesar 0,758, nilai t-statistics sebesar 16,153 dan 
lebih besar dari nilai t-table yaitu 1,96 dan nilai $\mathrm{p}$-value sebesar 0,000 yang artinya lebih kecil dari 0,05. Dengan demikian $\mathrm{H} 1$ dapat dibuktikan. Nilai koefisien beta bertanda positif mengindikasikan bahwa hubungan keduanya positif. Artinya, semakin baik citra sebuah destinasi maka akansemakin tinggi kepuasan wisatawan terhadap daerah tujuan wisata halal Pulau Lombok.

b. Pengaruh citra destinasi terhadap loyalitas wisatawan (H2) sebesar 0,426, nilai t-statistics sebesar 5,125 lebih besar dari nilai t-tabel 1,96, dan nilai pvalue sebesar 0,000 yang artinya lebih kecil dari 0,05. Dengan demikian hipotesis H2dapat dibuktikan, nilai koefisien beta bertanda positif mengindikasikan bahwa hubungan keduanya positif. Artinya semakin tinggi citra destinasi, maka akan semakin tinggi pula tingkat loyalitas wisatawan.

c. Pengaruh variabel kepuasan wisatawan terhadap loyalitas wisatawan (H3) sebesar 0,409 dengan nilai t-statistics sebesar 4,723 lebih besar dari nilai ttable 1,96 dan nilai $p$-value sebesar 0,000 lebih kecil dari 0,05. Dengan demikian $\mathrm{H} 3$ dapat dibuktikan, nilai koefisien beta bertanda positif mengindikasikan bahwa hubungan keduanya bersifat positif. Artinya, semakin tinggi kepuasan yang dirasakan wisatawan maka akan semakin tinggi pula loyalitas wisatawan terhadap daerah tujuan wisata halal Pulau Lombok

\section{PENUTUP \\ Kesimpulan}

Adapun kesimpulan yang berkaitan dengan penelitian ini yaitu: (1) Citra destinasi berpengaruh terhadap loyalitas wisatawan.(2) Citra destinasi berpengaruh terhadap kepuasan wisatawan. (3) Kepuasan wisatawan berpengaruh terhadap loyalitas wisatawan.

\section{Saran}

Adapun saran yang berkaitan dengan penelitian ini yaitu kepada pemangku kebijakan dan masyarakat Pulau Lombok tetap menjaga citra baik dari pariwisata Lombok sebagai daerah tujuan wisata halal Indonesia dan dunia.

\section{DAFTAR PUSTAKA}

[1] Artuğer, S., Çetinsöz, B. C., Kılıç, I., (2013). The effect of destination image on destination loyalty: application in Alanya. European Journal of Business and Management, 5 (13) : 124-136.

[2] Court, B. C., \& Lupton, R. A. (1997). Customer portfolio development: Modeling destination adopters, inactives, and rejecters. Journal of Travel Research, 36(1), 35-43.

[3] Gartner, W. C. (1989). Tourism image: Attribute measurement of state tourism products using multidimensional scaling techniques. Journal of Travel Research, 28(2), 16-20.

[4] Kotler, P., \& Keller, K.L. (2009) Manajemen Pemasaran, (Jakarta:Erlangga, 2009), 179-180.

[5] Kozak, M., \& Rimmington, M. (2000). Tourist satisfaction with Mallorca, Spain, as an off season holiday destination. Journal of Travel Research, 38(1), 260269.

[6] Lee, Y. K., Back, K. J., \& Kim, J. Y. (2009). Family restaurant brand personality: Its impact on customer's emotion, satisfaction, and brand loyalty. Journal of Hospitality and Tourism Research, 33(3), 305-328.

[7] Lopes \& Ferreira, S. D. (2011). "Destination image: Origins, Development and Implications", Revista de Turismo y Patrimonio Cultural, 307-311.

[8] Lovelock, Wirtz, \& Mussry. (2010), Pemasaran Jasa Manusia, Teknologi, Strategi. Jakarta: 
[9] Oliver, R. L. (1997). Satisfaction: A behavioral perspective on the consumer. New York: McGrawHill.

[10] Tasci, A. D. A. \& Metin Kozak. (2006). Destination brands vs destination images: Do we know what we mean?. Journal of Vacation Marketing, 12 (4), p. 299-185.

[11] Tasci, A. D. A., \& Gartner, W. C. (2007). Destination image and its functional relationships. Journal of Travel Research, 45(4), 413-425.

[12] Yamin, S., \& Kurniawan, H. (2011). Partial Least Square Path Modeling. Salemba Infotek 
HALAMAN INI SENGAJA DIKOSONGKAN 
HALAMAN INI SENGAJA DIKOSONGKAN 